\title{
Reports
}

\section{KKDIK Pre-Registration Deadline on the Doorstep}

\author{
Yaprak Yüzak Küçükvar*
}

\section{Introduction}

Turkey transposed the EU REACH Regulation ${ }^{1}$ within the framework of harmonization of European Union acquis. Turkish regulation known as KKDIK ${ }^{2}$, same acronym than REACH in Turkish language, was published on June 2017 and entered into force in December 2017. Several ministries in Turkey are closely following EU regulations for several sectors not only chemicals but also regulations relating to product groups such as fertilizers, pharmaceuticals, medical devices and electrical, electronical products. However, recent developments in the EU and global changes in chemical management strategies have pushed Turkey to speed up the harmonization process for chemicals in order to improve the conditions of trade between the EU and Turkey. Turkey being a member of G2o and having a Customs Union with the EU had to rapidly upgrade its regulatory regime to protect human health and the environment to meet the requirements of EU Member States. KKDIK replaced CICR, the former chemicals inventory regulation ${ }^{3}$ which was actually an exercise in preparation for a more complex regulation. KKDIK

DOI: $10.21552 / \mathrm{icrl} / 2020 / 2 / 7$

* Dr Yaprak Yuzak Kucukvar is the Director, Global Regulatory Affairs and Product Stewardship of REACH Global Services Group. For Correspondence: <yaprak@reach-gs.eu>.

1 Regulation (EC) No 1907/2006 of the European Parliament and of the Council of 18 December 2006 concerning the Registration, Authorisation and Restriction of Chemicals(REACH), establishing a European Chemicals Agency, amending Directive 1999/45/EC and repealing Council Regulation (EEC) No 793/93 and Commission Regulation (EC). No 1488/94 as well as Council Directive 76/769/EEC and Commission Directives 91/155/EEC, 93/67/EEC, 93/105/EC and 2000/21/EC [2006] OJ L 396/1

2 Kimyasalların Kaydı, Değerlendirilmesi, İzni ve Kısıtlaması Hakkında Yönetmelik [2017] Turkish Official Gazette No 30105 (Mükerrer).

3 Kimyasalların Envanteri ve Kontrolü Hakkında Yönetmelik [2008] Turkish Official Gazette No 27092 (Mükerrer.)

4 Maddelerin ve Karıșımların Sınıflandırılması, Etiketlenmesi ve Ambalajlanması Hakkında Yönetmelik [2013] Turkish Official Gazette No 28848 (Mükerrer) affects all manufacturers in Turkey and importers placing substances, mixtures and articles on the Turkish market. KKDIK does not only directly influence Turkish manufacturers but also impacts manufacturers located outside of Turkey with interest in the Turkish market. The non-Turkish manufacturers placing chemicals on the market may prefer to put the compliance burden on their Turkish subsidiaries' shoulders or go through the process of appointing an 'Only Representative' according to Article 9 of KKDIK. The heavy regulatory workload means that non-Turkish manufacturers must be meticulous when selecting a local Only Representative.

\section{KKDIK Pre-Registration Phase Ends by the End of 2020}

According to Article 7 of KKDIK, any manufacturer or importer of a substance, either on its own or in a mixture in quantities of one ton or above per year must submit a registration dossier to the Ministry of Environment and Urbanisation (MoEU) which is responsible for the implementation of KKDIK. The MoEU's online Chemicals Registration System (KKS) is used for pre-registrations and future registration dossier submissions. KKS has already been used by companies for Turkish CLP; By-Law on Classification, Labelling and packaging of hazardous substances and mixtures (SEA) ${ }^{4}$ notifications since 2013.

In order to register a substance, all potential registrants must submit information on the identity of the substance and its role in their supply chain to the MoEU through KKS by the 31 December 2020. Although this process is similar to the pre-registration performed in ECHA REACH-IT system, the term 'joining pre-SIEF' is often used in KKDIK guidance 
documents ${ }^{5}$. However, the term pre-registration is mostly used in this paper to facilitate better understanding.

\section{Obligations for Substances Placed on the Market after 2020}

The MoEU ${ }^{6}$ had recently announced that pre-registrations will remain open after the deadline for substances put on the market for the very first time after the deadline of $31^{\text {st }}$ December 2020. Besides this exception it is strongly recommended to complete pre-registrations until the deadline, 31/12/2020, for effective functioning of the joint registration process and also to be on the safe side if it is anticipated that the annual substance volume may reach or exceed 1 ton threshold anytime.

As in EU REACH, Inquiry Process shall be the procedure to follow for companies placing chemicals on the Turkish market for the first time after 31 December 2023 which is the ultimate deadline for registration.

\section{Becoming a SIEF (MBDF) Member}

All potential registrants, importers or downstream users, third parties who have submitted information on substances to MoEU's Chemicals Registration System, KKS, do automatically join the corresponding Substance Information Exchange Forum; MBDF. The aim of each MBDF is clearly explained in KKDIK Article 25(2);

1) Facilitate for the purpose of registration, the exchange of the information between potential registrants, thereby avoiding duplication of studies; and

2) Agree classification and labelling where there is a difference in the classification and labelling of the substance between potential registrants

MBDF enables all potential registrants and data holders to interact and prepare for registration. Manufacturers, importers and Only Representatives have to pre-register and join ön-MBDF (pre-SIEF) for joint registration of their substances through KKS. Companies joining ön-MBDF can reach potential registrants' contact information through KKS. The MoEU urges manufacturers, importers and only represen- tatives interested in the registration of the same substance to start communications for data and cost sharing negotiations required for registration. The ECHA 'Guidance on Data Sharing' was translated into Turkish language with adaptations to the current Turkish laws and the main principles in data sharing ${ }^{7}$ are identical with those of the EU.

'SIEF Facilitator' function do not exist in KKS yet and any company willing to initiate a communication can send an e-mail to potential registrants. There have been few communications made this year.

\section{Draft KKDIK Fees}

The following procedures are subject to payment according to $\mathrm{KKDIK}^{8}$ : (Article 59)

- Registration

- Registration update

- Confidentiality request for information

- Process and Product Orientated R\&D (PPORD) notifications

- Authorization application

- Review of Authorizations

A Draft KKDIK Fees List ${ }^{9}$ has been published that includes the fees for registration, registration update, non-public access information request, and process and product orientated R\&D (PPORD) notifications. It is stated that the final KKDIK Fee list will be published in early 2021. Since the authorization provisions will enter into force on $31 / 12 / 2023$, fees for the authorization process will be determined at a later stage.

Manufacturers in Turkey placing chemicals on the EU/EEA market have already registered the substances according to the obligations of EU REACH Regulation and paid their ECHA fees as well as Let-

5 For MoEU Guidance Documents see $<$ https://cygm.csb.gov.tr/kimyasallar-yonetimi-dairesi-baskanligii-87372> accessed 03 November 2020.

6 For MoEU Announcement see <https://kimyasallar.csb.gov.tr/kayit-sureci-yaklasiyor/331> accessed 03 November 2020.

7 MoEU Guidance for Data Sharing (2017) <http://webdosya.csb.gov.tr/db/cygm/icerikler/veri-paylasim-rehberi-20180731110208.docx> accessed 03 November 2020.

8 Kimyasalların Kaydı, Değerlendirilmesi, İzni ve Kısıtlaması Hakkında Yönetmelik [2017] Turkish Official Gazette No 30105 (Mükerrer).

9 For MoEU Fees List Announcement see <https://kimyasallar.csb.gov.tr/taslak-kkdik-ucretleri/333> accessed 03 November 2020. 
ter of Access fees to have the right to refer to the REACH data in their dossiers. Turkish KKDIK Registrations of the same substances compliant with the EU REACH Regulation, will be submitted to MoEU separately with a dossier prepared online in Turkish language. MoEU registration fees will need to be paid in accordance with KKDIK after submission of the dossier. There has been quite a lot of discussions for the last few years within and outside of Turkey about this duplicate effort needed for the dossier preparation and associated cost. Therefore, considering the economic conditions the industry is facing in Turkey as a result of the pandemic, MoEU has drafted fees with massive reductions from the initially anticipated numbers which would be identical with the ECHA fee figures but in Turkish currency. The other purpose of the reduced fee structure drafted is to support the companies under difficult conditions resulting from Covid 19 pandemic. Special reduced fees are defined for SMEs in the Draft KKDIK Fees List. There is a significant cost advantage for companies that will perform joint submission in line with the EU's approach for REACH registration fees. The lowest fee is determined as 50 Turkish Lira for joint registration of a substance in 1-10 tonnage band for micro sized enterprises. The highest figure is 15000 Turkish Lira for single submission of a substance of over 1000 tonnes for a large enterprise. Draft KKDIK Fee Structure can be accessed from MoEU website. ${ }^{10}$

\section{Latest Figures from MoEU}

The KKS is under re-construction and improvements of the system are implemented via an IPA ${ }^{11}$ (Instrument for pre-accession assistance) project co-financed by the EU and Turkish government. The project started in November 2019 and will last for two years. It is foreseen that the upgraded KKS will be in line with the latest version of IUCLID, and will

10 For MoEU Fees List Announcement see < https://kimyasallar.csb.gov.tr/taslak-kkdik-ucretleri/333> accessed 03 November 2020.

11 MoEU Project Opening (2020) see <https://kimyasallar.csb.gov.tr/kimyasal-guvenlik-degerlendirmesi-projeninac\%C4\%B1/\%C4\%B1s-semineri/314> accessed 03 November 2020.

12 MoEU Guidance for Data Sharing (2017) <http://webdosya.csb.gov.tr/db/cygm/icerikler/veri-paylasim-rehberi-20180731110208.docx> accessed 03 November 2020. be online before the end of 2020 while developments continue. Integration of a chemical safety assessment tool similar to Chesar and introduction of other user friendly functionalities to KKS are also part of the improvements planned for KKS under the IPA project. The MoEU officials recently stated unofficially that 95.000 pre-SIEFs were sent to the MoEU via KKS for above 15.000 substances. The numbers are expected to increase by the end of the year with last minute pre-registrations.

\section{Use of REACH Data}

All chemicals placed on the Turkish market shall be registered by 31 December 2023, according to KKDIK. Although a three-year registration time frame starting in January 2021 worries some companies, it is without doubt that the required data for most of the substances have already been compiled in EU REACH registration lead dossiers. If the substance is not registered for EU REACH, then a data gap analysis needs to be done and required tests must be completed to compile the KKDIK Registration dossier.

The information requirements which are listed in KKDIK Annexes 7 to 10 for different tonnage bands are identical with EU REACH Regulation. MoEU also translated most of ECHA's guidance documents into Turkish, including guidance on data sharing ${ }^{12}$. Initial discussions for the use of existing data sets for KKDIK Registrations have already started and encouraged by the members at some EU consortia. The aim is to avoid additional testing for regulatory compliance in other regions and make use of the available data by providing a Letter of Access for registrants in Turkey. This has already been practiced under the consortia for other global regulations, notably under K-REACH.

As no agreement has been reached between the Turkish government and the European Commission regarding REACH data and the duplication of costs associated with the rights to use it in Turkey, this remains the major compliance cost and a workload for potential registrants to create the similar dossiers in Turkish. Entry of information in KKS is requested in Turkish language including study summaries. However, additional test reports can apparently be submitted in English according to non-official verbal statements of MoEU officials. Thus, this issue still needs an official confirmation 
Some consortia have already calculated the cost of rights to use the REACH datasets for KKDIK compliance while many are working to determine a methodology for data transfer between EU registrants and potential Turkish registrants, with the legal and practical issues to be managed accordingly. The benefits of establishing a Turkish consortium or managing the process through the MBDF as experienced in REACH is being discussed by potential Turkish registrants and global manufacturers through their ORs or Turkish subsidiaries.

\section{Conclusion}

MoEU has shown a continuous effort to harmonise Turkish chemicals regulations with the EU since 2008 but there is still a transitional period until all chemicals in the Turkish market are completely registered and in line with the EU REACH Regulation. The
Amendment to Turkish By-Law on Classification, Labelling and packaging of hazardous substances and mixtures (SEA) including the $13^{\text {th }}$ ATP of EU CLP is expected to be published before the end of 2020. Other developments in the EU such as EU Chemicals Strategy for sustainability and regulations like EU PIC and POPs are closely followed and harmonisation efforts continue.

No data no market principle applies in Turkey after 2023 when all substances in the market will be KKDIK registered. Finally, one registration dossier for one substance approach is encouraged and highly supported by the reduced MoEU registration fees for joint submission of dossier.

The pre-registration phase of KKDIK forces all manufacturers and importers to create their inventory for Turkey very carefully. If Turkey is an important market for non-Turkish manufacturers, some obligations need to be met via an Only Representative or a Turkish subsidiary. 